\title{
Removal of Nutrients and Selected Heavy Metals in Wet Market Wastewater by Using Microalgae Scenedesmus sp.
}

\author{
Noor Maisara bte Jais ${ }^{1, a}$, Radin Maya Saphira bte Radin Mohamed ${ }^{2, b}$, \\ Wan Asma Wan Mohamad Apandi ${ }^{3, c}$, Hazel Monica Matias Peralta ${ }^{4, d}$
}

\author{
1,2,3,4,Faculty of Civil and Environmental Engineering, \\ Universiti Tun Hussien Onn Malaysia, \\ Locked Bag 101, 86400 Parit Raja, Batu Pahat.Johor, Malaysia \\ anoormaisarajais@gmail.com, ’bmaya@uthm.edu.my, cwanasmaapandi@gmail.com, \\ dmonica@uthm.edu.my
}

\begin{abstract}
Keywords: Microalgae Scenedesmus sp., wet market wastewater, nutrient and heavy metal removals
\end{abstract}

\begin{abstract}
The wet market wastewater may lead to pollution, odour and aesthetic problems to the environment and society if not treating properly. Thus, this research was conducted to culture microalgae Scenedesmus sp. and to identify the optimal concentration of microalgae Scenedesmus sp. due to the nutrient and heavy metal removals from wet market wastewater based on laboratory scale. The samples were taken from Public Market Parit Raja, Batu Pahat at 9a.m. in the morning as a peak hour operating stall using grab sampling technique. The characteristics of raw wastewater and microalgae Scenedesmus sp. were determined. There are five sample wastewater (used $625 \mathrm{ml}$ for each five sample wastewater) with five different samples concentration of microalgae which are $6.50 \times 10^{5}, 49.88 \times 10^{4}, 34.75 \times 10^{4}, 19.63 \times 10^{4}$ and $49.88 \times 10^{4}$ cell/ml with 16 days as duration for period study. The microalgae were cultured by BBM for eight days and another eight days for treatment with replicates three times for each sample. The analysis were measured due to the nutrient and heavy metal removals which are TN, TP, TOC, Fe and Zn during eight days treatment process. Based on experimental result, the optimum removal efficiency for each concentration were achieved 45.6-86.4\% of nutrients and heavy metals. The highest amount of nutrient and heavy metal removals after wastewater treatment by microalgae are TN $74.77 \%$, TP $82.17 \%$, TOC $86.36 \%$, Fe $65.76 \%$ and $\mathrm{Zn} \mathrm{84.14 \% .} \mathrm{As} \mathrm{conclusion} \mathrm{for} \mathrm{this} \mathrm{experiment,} \mathrm{Sample} 2$ (concentration $49.88 \times 10^{4}$ cell $/ \mathrm{ml}$ of microalgae Scenedesmus sp.) is the optimum concentration due to the highest percentage of nutrients and heavy metals removal which achieved $65.3-82.1 \%$ which TN $65.32 \%$, TP $76.77 \%$, TOC $80.34 \%$, Fe $65.76 \%$ and Zn $82.12 \%$.
\end{abstract}

\section{Introduction}

In Malaysia, the wet market activities contribute to unpleasant odour and dirty environment because the discharge were directly to the drainage without any treatment. This problem may lead to uncomfortable condition to buyers, sellers and residents at wet market area [1]. Moreover, the wastewater flow directly into drainage in that area may cause the drain clogged and the problem getting worst if no action taken by responsible person [2].

Microalgae had been choose as new technology to treat wastewater because it cheap and easily to handle because of their capabilities during photosynthesis process and eutrophication if wastewater contains excessive amount of nitrogen and phosphorus which able to incorporate with some nutrients such nitrogen and phosphorus [3]. From previous studies, there still less information about wet market wastewater treatment using microalgae cause the researches were focused on special media from laboratory, municipal wastewater, industrial wastewater and animal wastewater [4,5]. From analysis findings, the best result analysis is from Korea where this research had been using microalgae Scenedesmus sp. to treat swine wastewater by fermentation process which involved aeration system for 7 days and from the results, the removal efficiency nutrient for TN was $95 \%$, TP was $86 \%$, SS was $88 \%$ and $\mathrm{pH}$ was $13 \%$ [4]. The study of treatment of drainage solution 
from hydroponic greenhouse production with microalgae Chlorella vulgaris had done by Hultberg (2012) from Sweden with the large reduction in nutrients which phosphorus was $99.7 \%$ while nitrogen was $20.7 \%$ removal efficiency was achieved [6]. Microalgae Scenedesmus sp. and Chlorella sp. have good efficiency for heavy metals removal such as Iron (Fe) and Zinc (Zn) [3].

Therefore, the objectives of this study were to culture the microalgae Scenedesmus sp. and to identify the optimal concentration of microalgae Scenedesmus sp. due to the nutrient and heavy metal removals from wastewater by this type of treatment.

\section{Materials and Methods}

\section{Sampling of Wet Market Wastewater}

10 liters of wastewater was collected for the sampling. The duration of this sampling is on peak hour operating stall which around 9.00a.m. in the morning and the samples were analyzed in UTHM Environmental Laboratory.

\section{Characterization of Wet Market Wastewater}

In this study, the wastewater characteristics that were determined are biochemical oxygen demand (BOD), chemical oxygen demand (COD), total suspended solid (TSS), sulfate, total chlorine, $\mathrm{pH}$, turbidity, temperature and oil and grease. Table 1 below shows the parameters were monitored during the wastewater characteristic operations and methods that were used by using Hach DR 5000 Spectrophotometer.

Table 1. Characteristics of Wastewater and Methods

\begin{tabular}{|c|c|}
\hline Wastewater Characteristics & Methods \\
\hline Biochemical Oxygen Demand (BOD) & $\begin{array}{c}\text { Standard Method APHA } \\
5210 \text {-B }\end{array}$ \\
\hline Chemical Oxygen Demand (COD) & $\begin{array}{c}\text { Standard Method APHA } \\
5220 \text {-D }\end{array}$ \\
\hline Total Suspended Solid (TSS) & $\begin{array}{c}\text { Standard Method APHA } \\
2540 \text {-D }\end{array}$ \\
\hline Sulfate & $\begin{array}{c}\text { Sulfa Ver4 Method } \\
\text { (Method 8051, DR5000) }\end{array}$ \\
\hline Total Chlorine & $\begin{array}{c}\text { Mercuric Thiocyanate Method } \\
\text { (Method 8113, DR 5000) }\end{array}$ \\
\hline pH & $\begin{array}{c}\text { Standard Method APHA } \\
4500 \text {-H B }\end{array}$ \\
\hline Turbidity & $\begin{array}{c}\text { Attenuated Radiation Method } \\
\text { (Method 10047, DR5000) }\end{array}$ \\
\hline Temperature & $\begin{array}{c}\text { Standard Method APHA } \\
5220 \text {-D }\end{array}$ \\
\hline Oil and Grease & $\begin{array}{c}\text { USEPA } \\
\text { Hexane Extractable Gravimetric Method } \\
\text { (Method 10056) }\end{array}$ \\
\hline
\end{tabular}

(Source: Department of Civil and Environmental Engineering, UTHM, 2013)

\section{Characterizations of Microalgae Scenedesmus sp.}

Scenedesmus sp. are green algae which commonly found in the plankton of freshwater rivers, ponds, lakes, and sometimes in brackish habitats [7]. The advantages of using microalgae Scenedesmus sp. over the other available feedstock such as inorganic nutrients which preferred to the nitrogen, phosphorus and carbon are essential the following: their rapid growth rate, productivity and these microalgae are able to grow in a variety of environmental conditions [8]. 


\section{Experimental Design}

1) Culturing Microalgae and Concentration of Microalgae Scenedesmus sp. for Treatment Process

The culturing for this study had done by using Bolts Basal Medium (BBM) which additional of some stock solutions consisted of $\mathrm{NaNO}_{3} 25 \mathrm{~g} / 1, \mathrm{CaCl}_{2} .2 \mathrm{H}_{2} \mathrm{O} 2.5 \mathrm{~g} / \mathrm{l}, \mathrm{MgSO}_{4} .7 \mathrm{H}_{2} \mathrm{O} 7.5 \mathrm{~g} / \mathrm{l}$, $\mathrm{K}_{2} \mathrm{HPO}_{4} 7.5 \mathrm{~g} / 1, \mathrm{KH}_{2 \mathrm{PO}} 417.5 \mathrm{~g} / \mathrm{l}, \mathrm{NaCl} 2.5 \mathrm{~g} / \mathrm{l}$, EDTA $50.0 \mathrm{~g} / \mathrm{l}, \mathrm{KOH} 31.0 \mathrm{~g} / 1, \mathrm{FeSO}_{4} .7 \mathrm{H}_{2} \mathrm{O} 4.98 \mathrm{~g} / 1$, $\mathrm{H}_{2} \mathrm{SO}_{4} 1 \mathrm{ml}, \mathrm{H}_{3} \mathrm{BO}_{3} 11.42 \mathrm{~g} / \mathrm{l}$ and $1 \mathrm{ml}$ of trace elements solution $\left(\mathrm{ZnSO}_{4} .7 \mathrm{H}_{2} \mathrm{O} 8.82 \mathrm{~g} / \mathrm{l}\right.$, $\mathrm{MnCl}_{2} .4 \mathrm{H}_{2} \mathrm{O} 1.44 \mathrm{~g} / 1, \mathrm{MoO}_{3} 0.71 \mathrm{~g} / 1, \mathrm{CuSO}_{4} .5 \mathrm{H}_{2} \mathrm{O} 1.57 \mathrm{~g} / 1$ and $\left.\mathrm{Co}\left(\mathrm{NO}_{3}\right)_{2} \cdot 6 \mathrm{H}_{2} \mathrm{O} 0.49 \mathrm{~g} / \mathrm{l}\right)$ to the distilled water and autoclave the microalgae Scenedesmus sp. at $121^{\circ} \mathrm{C}$ (15PSI for 15 minutes) [9].

2) Lab Batch Reactor Preparation for Treatment Process

These microalgae were cultured within 8days before started the wet market wastewater treatment process. The five sets of sample wastewater were prepared and the concentration of microalgae Scenedesmus sp. that were used are $6.50 \times 10^{5}, 49.88 \times 10^{4}, 34.75 \times 10^{4}, 19.63 \times 10^{4}$ and $4.50 \times 10^{4} \mathrm{cell} / \mathrm{ml}$. These five different concentrations were repeated three times to get accurate readings. Each sample was used to measure the amount of nutrients and elements removal on $0,2^{\text {nd }}$, $4^{\text {th }}, 6^{\text {th }}$ and $8^{\text {th }}$ day. There are three different apparatus were used to measure the nutrients and heavy metals removal due to the laboratory analysis parameter which Total Organic Carbon Analyzer (TOC): TOC-VCSH used for TN and TOC, Ion Chromatography System (ICS-2000) used for TP while Flame Atomic Absorption Spectrometry (AAS) used for heavy metals Fe and Zn.

3) Calculation of Removal Efficiency

The percentage removal of nutrients and heavy metals was used to determine how efficient the treatment process by microalgae. In wastewater, the percentage removal of TN, TP, TOC, Fe and $\mathrm{Zn}$ can be determined by the following equation:

$$
\frac{\left(\mathrm{C}_{0}-\mathrm{C}_{\mathrm{i}}\right)}{\mathrm{C}_{0}} \times 100 \%=\% \text { Removal }
$$

where $\mathrm{C}_{0}$ represents nutrient concentration at the beginning experiment while $\mathrm{C}_{\mathrm{i}}$ represents the nutrients concentration on the day which reading taken during the wet market wastewater treatment process [10].

\section{Result and Discussions}

\section{Wet Market Wastewater Characteristics}

Table 2 shows the characteristics of raw wastewater from Public Market Parit Raja compared to previous research by Zulkifli [2].

Table 2. Characteristics Wet Market Wastewater

\begin{tabular}{|c|c|c|}
\hline Parameter & $\begin{array}{c}\text { Public Market Parit } \\
\text { Raja }\end{array}$ & $\begin{array}{c}\text { Pasar Ampangan } \\
\text { (Zulkifli, 2011) }\end{array}$ \\
\hline $\mathrm{pH}$ & $6.0 \pm 0.1$ & $5.6-5.8$ \\
\hline Turbidity (NTU) & $66.0 \pm 8.9$ & - \\
\hline Biochemical Oxygen Demand, BOD (mg/l) & $89 \pm 3.61$ & $31-122$ \\
\hline Chemical Oxygen Demand, COD (mg/l) & $456 \pm 8.19$ & $60-122$ \\
\hline Total Suspended Solid, TSS (mg/l) & $132.3 \pm 1.7$ & - \\
\hline Sulfate, $\mathrm{SO}_{4}{ }^{--}(\mathrm{mg} / \mathrm{l})$ & $32.3 \pm 0.78$ & - \\
\hline Total Chlorine, Cl ${ }^{-}(\mathrm{mg} / \mathrm{l})$ & $32 \pm 0.69$ & $30.3-37.3$ \\
\hline Total Nitrogen, TN (mg/l) & $36.9 \pm 0.5$ & $\mathrm{ND}-22.2$ \\
\hline Total Phosphorus, TP (mg/l) & $1.61 \pm 0.13$ & - \\
\hline Total Organic Carbon, TOC (mg/l) & $118.67 \pm 2.89$ & - \\
\hline Oil and Grease & $5.22 \pm 0.07$ & - \\
\hline Zinc, Zn (mg/l) & $0.312 \pm 0.0021$ & 13 \\
\hline Ferum, Fe (mg/l) & $1.071 \pm 0.0010$ & \\
\hline
\end{tabular}


Based on the Table 3, the value for COD and BOD were $456 \pm 8.19 \mathrm{mg} / \mathrm{l}$ and $89 \pm 3.61 \mathrm{mg} / \mathrm{l}$ for BOD in Public Market Parit Raja while COD and BOD from Pasar Ampangan were 381 to 560 $\mathrm{mg} / \mathrm{l}$ and BOD in Pasar Ampangan is 71 to $122 \mathrm{mg} / \mathrm{l}$ which shows that both value for COD and BOD from Public Market Parit Raja wastewater is in range by the Pasar Ampangan wastewater. For $\mathrm{pH}$ value comparison, it shows that the range of $\mathrm{pH}$ is 5.6 to 5.8 in Pasar Ampangan compared to $6.0 \pm 0.1$ in Public Market in Parit Raja where the wastewater from Parit Raja is less acidic than Pasar Ampangan because of less usage of detergents for washing floor. The value for TSS is $132.3 \pm 1.7 \mathrm{mg} / \mathrm{l}$ for Public Market Parit Raja wastewater which is higher than TSS in Pasar Ampangan where the value is 60 to $122 \mathrm{mg} / \mathrm{l}$. The total nitrogen, TN for Public Market Parit Raja wastewater is $36.9 \pm 0.5 \mathrm{mg} / \mathrm{l}$ and this value is similar compared to total nitrogen in Pasar Ampangan where the value is 30.3 to $37.3 \mathrm{mg} / \mathrm{l}$.

Efficiency Removal of Wet Market Wastewater Treatment by Microalgae Scenedesmus sp.

The nutrients such as nitrogen and phosphorus are the primary concerns in wastewater treatment. According to previous studies, microalgae are known to sequester heavy metal [3]. Table 3 below shows the highest percentage removal of nutrients and heavy metals for each five different concentration while Fig. 1 shows that the highest percentage nutrient (TN, TP and TOC) and heavy metal (Fe and $\mathrm{Zn}$ ) removals for each concentration which these highest efficiency removal results within 8 days treatment process.

Table 3. Highest Percentage Removal of Nutrients and Heavy Metals

\begin{tabular}{|c|c|c|c|c|c|}
\hline \multirow{2}{*}{ Nutrient } & \multicolumn{5}{|c|}{ Highest Percentage Removal (\%) } \\
\cline { 2 - 6 } & $\begin{array}{c}\text { Sample 1 } \\
\left(6.50 \times 10^{5}\right. \\
\text { cell/ml })\end{array}$ & $\begin{array}{c}\text { Sample 2 } \\
\left(49.88 \times 10^{4}\right. \\
\text { cell/ml })\end{array}$ & $\begin{array}{c}\text { Sample 3 } \\
\left(34.75 \times 10^{4}\right. \\
\text { cell/ml })\end{array}$ & $\begin{array}{c}\text { Sample 4 } \\
\left(19.63 \times 10^{4}\right. \\
\text { cell/ml })\end{array}$ & $\begin{array}{c}\text { Sample 5 } \\
\left(4.50 \times 10^{4}\right. \\
\text { cell/ml })\end{array}$ \\
\hline TN & 74.77 & 65.32 & 46.03 & 51.52 & 50.71 \\
\hline TP & 79.75 & 76.77 & 82.17 & 82.07 & 79.29 \\
\hline TOC & 68.90 & 80.34 & 86.36 & 78.10 & 73.72 \\
\hline Fe & 55.77 & 65.76 & 59.79 & 61.21 & 45.60 \\
\hline Zn & 84.14 & 82.12 & 79.67 & 81.33 & 71.94 \\
\hline
\end{tabular}

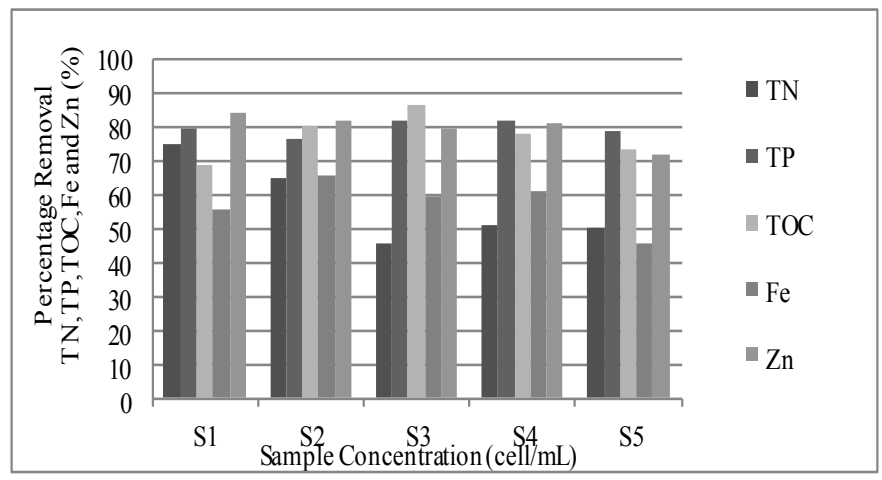

Fig. 1. Percentage nutrients and heavy metal removals against concentrations

From the Table 3, the maximum percentage removal for TN is $74.77 \%$ from Sample $1\left(6.50 \times 10^{5}\right.$ cell $/ \mathrm{ml})$ while the lowest percentage removal is $46.03 \%$ from Sample $3\left(34.75 \times 10^{4}\right.$ cell $\left./ \mathrm{ml}\right)$. Nitrogen reduction by microalgae which performed in wastewater with high concentration of TN is commonly from $60 \%$ to $90 \%$ [9]. The less concentration of microalgae cause the amount of TN cannot be removed perfectly from the wastewater. The maximum percentage removal for TP is $82.17 \%$ from Sample $3\left(34.75 \times 10^{4} \mathrm{cell} / \mathrm{ml}\right)$ and the minimum percentage removal for TP is $76.77 \%$ from Sample $2\left(49.88 \times 10^{4} \mathrm{cell} / \mathrm{ml}\right)$. For this study, the microalgae used lot of phosphorus amount as nutrients in this wastewater sample because the $\mathrm{PO}_{4}{ }^{3-}$ are not present in the atmosphere [11]. The third parameter, TOC from Sample $3\left(34.75 \times 10^{4}\right.$ cell $\left./ \mathrm{ml}\right)$ is $86.36 \%$ as the highest percentage removal and $68.90 \%$ from Sample $1\left(6.50 \times 10^{5}\right.$ cell $\left./ \mathrm{ml}\right)$ is the lowest percentage removal. 
Based on Table 3 and Fig. 1, the highest removal efficiency for Fe for treated wastewater is $65.76 \%$ for Sample $2\left(49.88 \times 10^{4}\right.$ cell $\left./ \mathrm{ml}\right)$ and $84.14 \%$ from Sample $1\left(6.50 \times 10^{5} \mathrm{cell} / \mathrm{ml}\right)$ for $\mathrm{Zn}$. Generally, heavy metal able to be removed in wastewater treatment with application of microalgae Scenedesmus sp.. The result as percentage maximum removal for $\mathrm{Zn}$ in treated wastewater in Public Market Parit Raja was lower when compared to previous research by Travieso where the maximum removal of Zn using Scenedesmus acutus was 91\% [12].

The highest of TN and Zn removal which $74.77 \%$ and $84.14 \%$ were obtained in Sample 1 $\left(6.50 \times 10^{5} \mathrm{cell} / \mathrm{ml}\right), \mathrm{TP}$ and TOC removal which $82.17 \%$ and $86.36 \%$ were obtained in Sample 3 $\left(34.75 \times 10^{4} \mathrm{cell} / \mathrm{ml}\right)$ and Fe removal which $65.76 \%$ were obtained in Sample $2\left(49.88 \times 10^{4} \mathrm{cell} / \mathrm{ml}\right)$. It clearly shows each concentration will give different value of percentage removal. Overally, the growth time on day 8 give good removal efficiency.

\section{Conclusion}

As conclusion, Sample 2 (concentration $49.88 \times 10^{4}$ cell $/ \mathrm{ml}$ of microalgae Scenedesmus $\mathrm{sp}$.) is the most efficient concentration due to the highest percentage of nutrients and heavy metals removal were achieved $65.3-82.1 \%$ which TN $65.32 \%$, TP $76.77 \%$, TOC $80.34 \%$, Fe $65.76 \%$ and $\mathrm{Zn}$ $82.12 \%$.

\section{References}

[1] Izzuddin, A., Ghani, Application of bioparticle \& constructed wetlands in treating wet market wastewater, Universiti Teknologi Malaysia: Undergraduate's Thesis 2011.

[2] Zulkifli A. R, Roshadah, H. \& Tunku Khalkausar T. F., Control of water pollution from nonindustrial premises. Department of Environment, Malaysia 2011.

[3] Abdel-Raouf N., Al-Homaidan A.A., Ibraheem I.B.M., Microalgae and wastewater treatment, Saudi J. of Bio. Sci. 19(3) (2012) 257-275.

[4] Kim M. K., Park J. W., Park C. S., Enhanced production of Scenedesmus sp. (green microalgae) using a new medium containing fermented swine urine, J. of Biore. Tech. 98 (2007) 2220-2228

[5] Salim, S., Vermuë, M. H., \& Wijffels, R. H., Ratio between autoflocculating and target microalgae affects the energy-efficient harvesting by bio-flocculation, Biore. Tech. 118 (2012) 4955.

[6] Hultberg, M., Carlsson, A. S., \& Gustafsson, S., Treatment of drainage solution from hydroponic greenhouse production with microalgae, Biore. Tech. 101 (2013) 8690-8697.

[7] Reddy S.M., University Botany I : (Algae, Fungi, Bryophyta and Pteridophyta. Scenedesmus). Vol.1 (2001) pp. 38-39.

[8] Prabakaran, P. \& Ravindran, A.D., Scenedesmus as a potential source of biodiesel among selected microalgae, Current Science, Vol. 102, No. 4, 2012.

[9] Nichols, H. W., Growth Media-Freshwater. In Stein, J. (Eds.) Handbook of Phycological Methods, Culture Methods and Growth Measurements, Cambridge University Press (1973)7-24.

[10]Zheng, Z.c., Li, T.X., Zeng, F.F., Zhang, X.Z., Yu, H.Y., Wang, Y.D., Liu, T., Accumulation characteristics of removal of nitrogen and phosphorus from livestock wastewater by Polygonum hydropiper, Agricultural Water Management, 117 (2013) 19-25.

[11] Mcelwee, K., Baker, J., \& Clair, D., Pond fertilization : Ecological approach and practical application, Oregon State University: Aquaculture Collaborative Research Support Program, 2006.

[12] Travieso L., Canizares R. O., Borja R., Benitez F., Dominguez R., Dupeyron R. \&Valiente V., Heavy metal removal by microalgae, Bulletin Environmental Contamination and Toxicology. 62 (1991)144-151. 